\title{
PTERYGIUM EXCISION WITH SUTURELESS GLUELESS CONJUNCTIVAL AUTOGRAFTING: AN EXPERIENCE OF 30 CASES
}

\author{
Jawed Alam¹, Himadri Bhattacharjya², Abhijit Ray33, Madhu Sudan Das ${ }^{4}$
}

\section{HOW TO CITE THIS ARTICLE:}

Jawed Alam, Himadri Bhattacharjya, Abhijit Ray, Madhu Sudan Das. "Pterygium Excision with Sutureless Glueless Conjunctival Autografting: An Experience of 30 Cases". Journal of Evolution of Medical and Dental Sciences 2014; Vol. 3, Issue 12, March 24; Page: 3024-3029, D0I: 10.14260/jemds/2014/2239

ABSTRACT: BACKGROUND: Sutureless glueless conjunctival autografting in pterygium surgery is gaining popularity due to short surgical time, no recurrence and good cosmetic outcome. AIM: To see the outcome of pterygium excision with sutureless glueless conjunctival autografting. METHODS: 30 cases of uncomplicated pterygia irrespective of eyes, age and sex were examined with slit lamp. All were nasal pterygia \& progressive type. Blood sugar and xylocaine test were done. Pterygium mass was excised and autologous conjunctival graft without suture or glue were performed. Grafts were taken from inferotemporal area. Follow up was done on $1^{\text {st }}$ day, $7^{\text {th }} d a y, 45^{\text {th }}$ day and on $6^{\text {th }}$ month. RESULT: All the grafts were intact on each follow up. Graft retraction was present in one case on $7^{\text {th }}$ POD. No recurrence was found till 6th month follow up. CONCLUSION: No glue, no suture conjunctival grafting in pterygium surgery takes short surgical time, easy to perform, excellent cosmetic outcome with no recurrence.

KEYWORDS: Pterygium surgery, Sutureless Glueless Conjunctival autografting.

INTRODUCTION: Pterygium is a wing shaped fold of conjunctiva encroaching upon the cornea from either side within the interpalpebral fissure. ${ }^{1}$ It is more common in adult male involving in outdoor activities. The exact cause of pterygium is still not known, but ultra violet radiation of sunlight is supposed to be most common cause. This explains why pterygium occurs with increasing frequency in climate approaching the equator. Other causes include continuous exposure to dry and dusty environment. When eye is continuously exposed to such factor, the conjunctiva may thicken to form pterygium. This is basically degenerative as well as hyperplastic condition of conjunctiva. The subconjunctival tissue undergoes elastotic degeneration and proliferates as vascularized granular tissue under epithelium which ultimately encroaches cornea. ${ }^{2}$ This process causes redness, irritation and visual disturbances by disrupting the normal smooth surface of cornea. ${ }^{3}$ In severe cases, pterygium can block patient's vision altogether. ${ }^{3}$ Initially redness and irritation can be controlled by lubricant eye drops but when vision is affected by its growth and astigmatism, surgery is considered. Pterygium surgery has evolved significantly over time. The outcomes are significantly better than conventional pterygium surgery. In bare sclera technique, pterygium mass is excised and the underlying sclera left exposed. Unfortunately recurrence is upto $50 \%$ of the cases. This recurrence was reduced by filling the bare sclera. ${ }^{4}$ Conjunctival autografting in conventional autograft surgery; the stitches are used to secure the graft in place. But this technique takes more time for stitching and produces discomfort for several weeks. These complications lead to development of NO STITCH surgery using fibrin glue as an adhesive to secure the graft.5- 8 The fibrin glue causes risk of transmitting infections and reactions. All these lead to the development of sutureless glueless conjunctival autografting for covering bare sclera. Pterygium excision with sutureless glueless conjunctival autografting is gaining popularity due to its simpler technique and no recurrence. 
MATERIALS AND METHODS: Preoperative work up: During 1st July 2013 to 31 ${ }^{\text {st }}$ December 2013, 30 cases of pterygium were selected randomly irrespective of eyes, age, and gender. All the cases were examined with slit lamp. All pterygia were nasal and progressive type. Blood sugar, bleeding time, clotting time and xylocaine sensitivity tests were performed. Informed written consent was obtained from all the patients before surgery. Surgical technique: Conjunctiva over the pterygium mass was lifted and dissected $4 \mathrm{~mm}$ away and concentric to the limbus. At the same position pterygium mass was lifted and dissected. Pterygium mass was reflected towards the cornea with artery forceps. The mass was carefully dissected out from the cornea. At infero-temporal position conjunctiva was dissected in such a way that the graft becomes $1 \mathrm{~mm}$ larger than the bare sclera in all the directions. The grafts were pulled to the bare sclera and spread over it with the help of non-toothed forceps. Post-operative work up: Post-operative follow up was done for all the cases on the $1^{\text {st }}$ day, $7^{\text {th }}$ day, $45^{\text {th }}$ day and $6^{\text {th }}$ month. They were examined for pain and discomfort, graft dislocation, graft retraction, cosmetic view and other post-operative complications. Result of the study was expressed in terms of mean and percentages. Fisher's exact test was used to test the statistical significance and p-value less than 0.05 was considered statistically significant.

RESULTS: Total 30 cases underwent pterygium surgery with sutureless glueless conjunctival autografting. There were 22 male patients and 8 female patients. All of them had primary nasal pterygia. Average surgical time was 10 minutes.

\section{Table 1: The type of pterygium, gender of patients and the operative time taken}

\begin{tabular}{|l|l|c|c|}
\hline \multicolumn{1}{|c|}{ Variables } & \multicolumn{1}{|c|}{ Sub-groups } & Number & Percentage \\
\hline \multirow{2}{*}{ Type of pterygium } & Nasal & 30 & 100 \\
\cline { 2 - 4 } & Temporal & 0 & 0 \\
\hline \multirow{2}{*}{ Gender } & Male & 22 & 73.33 \\
\cline { 2 - 4 } & Female & 8 & 26.67 \\
\hline \multirow{3}{*}{ Operative time } & 8 minutes & 12 & 40 \\
\cline { 2 - 4 } & 10 minutes & 8 & 26.67 \\
\cline { 2 - 4 } & 15 minutes & 10 & 33.33 \\
\hline
\end{tabular}

Table 1 shows that all the patients had nasal pterygium, majority of them were male and most of the surgeries (40\%) took only 8 minutes. 


\begin{tabular}{|l|c|c|c|}
\hline \multicolumn{4}{|c|}{ Table 2: The outcome following pterygium surgery } \\
\hline \multicolumn{1}{|c|}{ Variables } & Sub-groups & Number & Percentage \\
\hline \multirow{2}{*}{ Graft dislocations } & Present & 0 & 0 \\
\cline { 2 - 4 } & Absent & 30 & 100 \\
\hline \multirow{2}{*}{ Graft retraction } & Present & 01 & 3.33 \\
\hline \multirow{3}{*}{ Post-operative pain } & Absent & 29 & 96.67 \\
\cline { 2 - 4 } & Mild pain & 10 & 33.33 \\
\cline { 2 - 4 } & Moderate pain & 0 & 0 \\
\cline { 2 - 4 } Cosmetic outcome & No pain & 20 & 66.67 \\
\cline { 2 - 4 } & Poor & 0 & 0 \\
\hline
\end{tabular}

Table 2 shows that none of the patients had graft dislocation, 3.33\% patients had graft retraction, $33.33 \%$ cases complained of mild pain during the early post- operative period and all the cases had good cosmetic outcome. There were no graft dislocations. There was only one graft retraction on the $7^{\text {th }}$ post-operative day. This was treated with topical steroid drops with tapering dose. On the $1^{\text {st }}$ post-operative day complain of mild pain was noted. All the patients were comfortable with good cosmetic outcome during the subsequent follow ups.

\section{Table 3: Bivariate analysis regarding cosmetic outcome following pterygium surgery}

\begin{tabular}{|c|c|c|c|c|}
\hline \multirow{2}{*}{\multicolumn{2}{|c|}{ Gender and operative time }} & \multicolumn{2}{|c|}{ Cosmetic outcome } & \multirow[b]{2}{*}{ Significance } \\
\hline & & \multirow{2}{*}{$\begin{array}{c}\begin{array}{c}\text { Good } \\
\text { Number (\%) }\end{array} \\
22(100) \\
\end{array}$} & \multirow{2}{*}{$\begin{array}{c}\text { Poor } \\
\text { Number (\%) } \\
0(0)\end{array}$} & \\
\hline \multirow{2}{*}{ Gender } & Male & & & \multirow{2}{*}{$\begin{array}{l}\text { Fisher's exact test } \\
P=1.00\end{array}$} \\
\hline & Female & $8(100)$ & $0(0)$ & \\
\hline \multirow{2}{*}{ Operative time } & $\leq 10$ minutes & $20(100)$ & $0(0)$ & \multirow{2}{*}{$\begin{array}{l}\text { Fisher's exact test } \\
\mathrm{P}=1.00\end{array}$} \\
\hline & $>10$ minutes & $10(100)$ & $0(0)$ & \\
\hline
\end{tabular}

Table 3 shows that gender of the patient and time taken for operation did not affect the cosmetic outcome of pterygium surgery though it was not significant $(\mathrm{p}=1.00)$.

No recurrence was noted up to the follow up at $6^{\text {th }}$ month.

\begin{tabular}{|l|l|c|c|c|}
\hline \multicolumn{4}{|c|}{ Table 4: Bivariate analysis regarding recurrence of pterygium following surgery } \\
\hline \multirow{2}{*}{ Gender and operative time } & \begin{tabular}{c} 
Recurrence at 6 months follow up \\
\multirow{2}{*}{ Aresent } \\
\cline { 2 - 4 }
\end{tabular} & $\begin{array}{c}\text { Absent } \\
\text { Number (\%) }\end{array}$ & \multirow{2}{*}{ Significance } \\
\hline \multirow{2}{*}{ Gender } & Male & $0(0)$ & $22(100)$ & \multirow{2}{*}{ Fisher's exact test } \\
& Female & $0(0)$ & $8(100)$ & P = 1.00 \\
\hline \multirow{2}{*}{ Operative time } & $\leq 10$ minutes & $20(100)$ & $0(0)$ & Fisher's exact test \\
\cline { 2 - 4 } & $>10$ minutes & $10(100)$ & $0(0)$ & P = 1.00 \\
\hline
\end{tabular}

Table 4 shows that gender of the patient and time taken for operation did not affect the recurrence of pterygium following surgery though it was not significant $(p=1.00)$. 
Cosmetic outcome and recurrence of pterygium following surgery was not affected by gender of the patients and time taken for surgery $(p=1.00)$.

DISCUSSION: Currently practiced surgical methods of pterygium excision include conjunctival autografting using suture or glue and sutureless glueless autografting. The presence of sutures may lead to prolong wound healing and fibrosis.7,9 Subsequent complications such as pyogenic granuloma formation are easily treated. Others such as symblepharon, forniceal contracture, ocular motility restriction, diplopia and sclera sclerosis and infection are much more difficult to manage and may be sight threatening. ${ }^{10,11}$ As the fibrin glue is manufactured from human plasma, it carries the risk of transmitting diseases. ${ }^{12}$ Most commonly hepatitis A and parvovirus B19 are prone to get transmitted through glue. The fibrinogen compounds may also be susceptible to inactivation by iodine preparations such as those used for conjunctival disinfection before pterygium surgery. Sutureless glueless conjunctival autografting in pterygium surgery is a simple technique with less surgical time. In this study approximately 10 minutes were required for each case. This noble technique is also less costly as no requirement of suture or glue. Our study was a non-randomised study performed among a small population with a relatively shorter period of follow up for 6 months. However, one article comparing four commonly used techniques for pterygium surgery reported mean time of any complication including recurrence was 4 months. ${ }^{13}$ In our study one case of graft retraction was found on the $7^{\text {th }}$ day of follow up. This was due to contraction of the subconjunctival tissue in the process of scar formation resulting in graft retraction. No graft dislocation was found. Till the $6^{\text {th }}$ month of follow up, no recurrence of pterygium mass was detected. All the patients were happy with good cosmoses.

CONCLUSION: No suture no glue conjunctival autografting in pterygium surgery is excellent in view of easy technique, short surgical time, lesser complications, excellent cosmetic view, and no recurrence. This surgery may stand in future with more experiences over time.

\section{REFERENCES:}

1. Stacey E Mills, Darryl Carter, Joel K Greenson, Victor E Reuter and Mark H Stoler. Sternberg's Diagnostic Surgical Pathology. $5^{\text {th }}$ edition, Vol. 1, Wolters Kluwer Health/ Lippincott Williams \& Wilkins, Baltimore, 03-Feb-2012.

2. Gerstenblith, Adam T and Rabinowitz, Michael P. The Wills eye manual: office and emergency room diagnosis and treatment of eye disease. 6th edition, Wolters Kluwer Health/Lippincott Williams \& Wilkins, Philadelphia, 2012.

3. Kunimoto, Derek Y, Kanitkar, Kunal D and Makar, Mary. The Wills eye manual: office and emergency room diagnosis and treatment of eye disease. 4th edition, Philadelphia: Lippincott Williams \& Wilkins, 2004.

4. Kenyon KR, Wagoner MD, Hettinger ME. Conjunctival autograft transplantation for advanced and recurrent pterygium. Ophthalmology 1985; 92:1461-1470.

5. Ayala M. Results of pterygium surgery using a biologic adhesive. Cornea 2008; 27:663-667.

6. Kim HH, Mun HJ, Park YJ, Lee KW, Shin JP. Conjunctivolimbal autograft using a fibrin adhesive in pterygium surgery. Korean J Ophthalmol 2008; 22:147-154. 


\section{ORIGINAL ARTICLE}

7. Koranyi G, Seregard S, Kopp ED. A no suture, small incision approach to pterygium surgery. Br J Ophthalmol 2004; 88:911-914.

8. Koranyi G, Seregard S, Kopp ED. The cut- and- paste method for primary pterygium surgery: long term follow up. Acta Ophthalmologica Scandinavica 2005; 83:298-301.

9. Allan BD, Short P, Crawford GJ, Barret GD, Constable IJ. Pterygium excision with conjunctival autografting: An effective and safe technique. Br J Ophthalmol 1993; 77:698-701.

10. Solomon A, Pires RT, Tseng SC. Amniotic membrane transplantation after extensive removal of primary and recurrent pterygia. Ophthalmology 2001; 108:449-460.

11. Vrabec MP, Weisenthal RW, Elsing SH. Subconjunctival fibrosis after conjunctival autograft. Cornea 1993; 12:181-183.

12. Ang LP, Chua JL, Tan DT. Currents concepts and techniques in pterygium treatment. Curr Opin Ophthalmol 2007; 18:308-313.

13. Alpay A, Ugurbas SH, Erdogan B. Comparing techniques for pterygium surgery. Clin Ophthalmol 2009; 3:69-74.

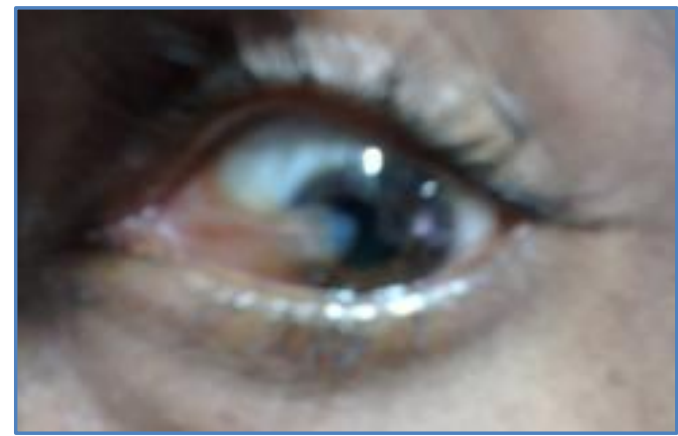

Picture 1: Before surgery

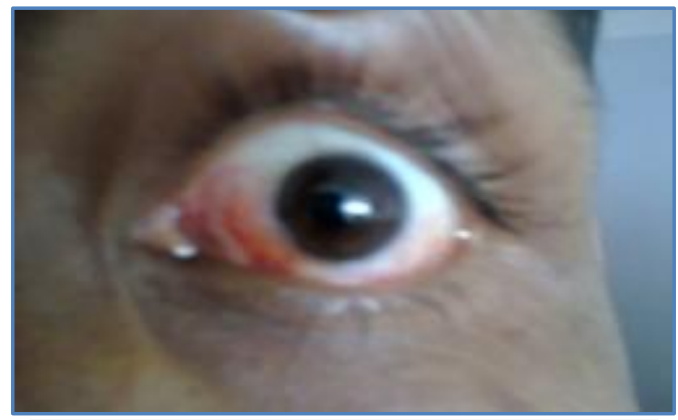

Picture $3: 45^{\text {th }}$ post-operative day

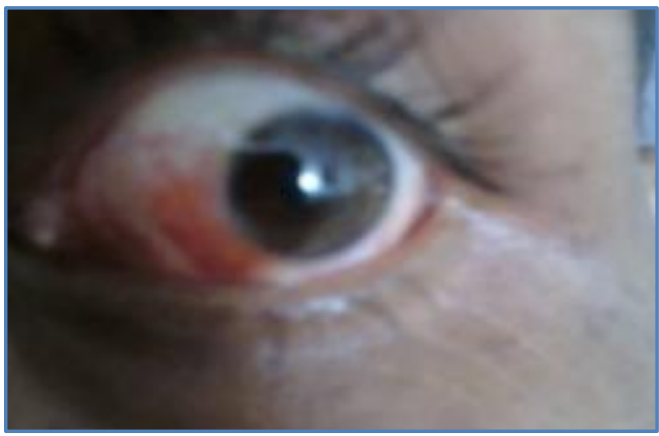

Picture 2: $1^{\text {st }}$ post-operative day

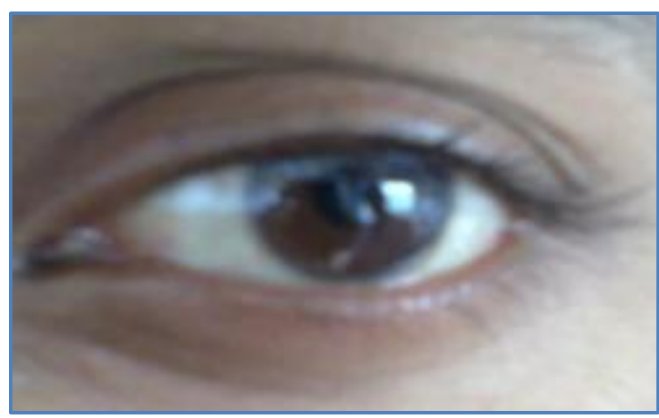

Picture 4: $6^{\text {th }}$ month post-operative 


\section{ORIGINAL ARTICLE}

\section{AUTHORS:}

1. Jawed Alam

2. Himadri Bhattacharjya

3. Abhijit Ray

4. Madhu Sudan Das

\section{PARTICULARS OF CONTRIBUTORS:}

1. Post Graduate Trainee, Department of Ophthalmology, Agartala Government Medical College.

2. Assistant Professor, Department of Community Medicine, Agartala Government Medical College.

3. Assistant Professor, Department of Ophthalmology, Agartala Government of Medical College.
4. Medical Officer, Tripura Health Service, Tripura.

\section{NAME ADDRESS EMAIL ID OF THE} CORRESPONDING AUTHOR:

Dr. Himadri Bhattacharjya, Assistant Professor,

Department of Community Medicine, Agartala Government Medical College, P. O Kunjavan, PIN - 799006,

Tripura, India.

E-mail: hbhattacharjya@rediffmail.com

Date of Submission: 20/02/2014. Date of Peer Review: 21/02/2014. Date of Acceptance: 04/03/2014. Date of Publishing: 19/03/2014. 